\section{TRENDS IN WORLD MILITARY EXPENDITURE, 2017}

\author{
NAN TIAN, AUDE FLEURANT, ALEXANDRA KUIMOVA, \\ PIETER D. WEZEMAN AND SIEMON T. WEZEMAN
}

World military expenditure is estimated to have reached $\$ 1739$ billion in 2017, the highest level since the end of the cold war. ${ }^{1}$ After 13 consecutive years of increases from 1999 to 2011 and relatively unchanged spending from 2012 to 2016, total global expenditure rose marginally in 2017, by 1.1 per cent in real terms (see figure 1). This Fact Sheet highlights the regional and national trends in 2017 and over the decade 2008-17 shown by new data from the SIPRI Military Expenditure Database. ${ }^{2}$

Military spending in 2017 represented 2.2 per cent of global gross domestic product (GDP) or $\$ 230$ per person. Military expenditure as a share of GDP-the 'military burden'-assesses the proportion of national resources dedicated to military activities and the burden on the economy. The global military burden has ranged from a post-cold war high of 3.3 per cent in 1992 to a low of 2.1 per cent in 2014 .

\footnotetext{
${ }^{1}$ All figures for spending in 2017 are given in 2017 current US dollars. Figures for relative increases or decreases in military spending are expressed in constant (2016) US dollars, often described as changes in 'real terms' or adjusted for inflation. The large differences in 2017 military expenditure when expressed in current 2017 US dollars compared with constant 2016 US dollars are caused by the overall depreciation of the US dollar against the currencies of the rest of the world.

2 The SIPRI Military Expenditure Database was updated on 2 May 2018 to include new data on military expenditure in 2017.
}

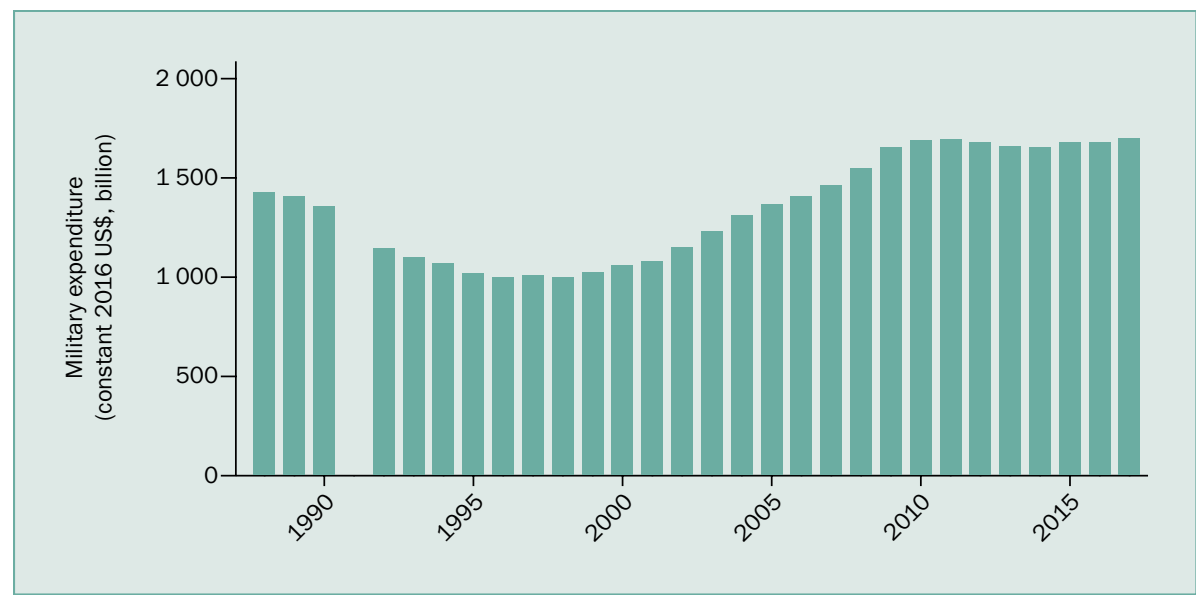

Figure 1. World military expenditure, 1988-2017

Note: The totals are based on the data on 172 states in the SIPRI Military Expenditure Database as of May 2018. The absence of data for the Soviet Union in 1991 means that no total can be calculated for that year.

\section{KEY FACTS}

- Global military expenditure was $\$ 1739$ billion in 2017 , an increase of 1.1 per cent in real terms on 2016.

- Total military spending accounted for 2.2 per cent of global gross domestic product in 2017.

- The five biggest spenders in 2017 were the United States, China, Saudi Arabia, Russia and India, which together accounted for 60 per cent of global military spending.

- Military expenditure by the USA was unchanged in 2017, at $\$ 610$ billion. China increased its military spending by 5.6 per cent, Saudi Arabia by 9.2 per cent and India by 5.5 per cent, while Russia's spending fell by 20 per cent.

- Military expenditure increased in sub-Saharan Africa, South America, Central and South Asia, East Asia and Central and Western Europe. The total military expenditure of the countries in the Middle East for which data is available also increased.

- Military spending decreased in North Africa, Central America and the Caribbean, Oceania and Eastern Europe.

- Military expenditure remained unchanged in North America and South East Asia. 
Table 1. The 15 states with the highest military expenditure in 2017

Spending figures and GDP are in US\$, at current prices and exchange rates. Changes are in real terms, based on constant (2016) US dollars. Figures may not add up to stated totals due to the conventions of rounding.

\begin{tabular}{|c|c|c|c|c|c|c|c|}
\hline \multicolumn{2}{|l|}{ Rank } & \multirow[b]{2}{*}{ Country } & \multirow{2}{*}{$\begin{array}{l}\text { Spending, } \\
2017 \text { (\$ b.) }\end{array}$} & \multirow{2}{*}{$\begin{array}{l}\text { Change, } \\
2008-17 \\
(\%)\end{array}$} & \multirow{2}{*}{$\begin{array}{l}\text { World } \\
\text { share, } \\
2017(\%)\end{array}$} & \multicolumn{2}{|c|}{$\begin{array}{l}\text { Spending as } \\
\text { a share of } \\
\operatorname{GDP}(\%)^{b}\end{array}$} \\
\hline 2017 & $2016^{a}$ & & & & & 2017 & 2008 \\
\hline 1 & 1 & USA & 610 & -14 & 35 & 3.1 & 4.2 \\
\hline 2 & 2 & China & [228] & 110 & [13] & [1.9] & [1.9] \\
\hline 3 & 4 & Saudi Arabia & {$[69.4]$} & 34 & {$[4.0]$} & {$[10]$} & 7.4 \\
\hline 4 & 3 & Russia & 66.3 & 36 & 3.8 & 4.3 & 3.3 \\
\hline 5 & 6 & India & 63.9 & 45 & 3.7 & 2.5 & 2.6 \\
\hline 6 & 5 & France & 57.8 & 5.1 & 3.3 & 2.3 & 2.3 \\
\hline 7 & 7 & $\mathrm{UK}$ & 47.2 & -15 & 2.7 & 1.8 & 2.3 \\
\hline 8 & 8 & Japan & 45.4 & 4.4 & 2.6 & 0.9 & 0.9 \\
\hline 9 & 9 & Germany & 44.3 & 8.8 & 2.5 & 1.2 & 1.3 \\
\hline 10 & 10 & South Korea & 39.2 & 29 & 2.3 & 2.6 & 2.6 \\
\hline 11 & 13 & Brazil & 29.3 & 21 & 1.7 & 1.4 & 1.4 \\
\hline 12 & 11 & Italy & 29.2 & -17 & 1.7 & 1.5 & 1.7 \\
\hline 13 & 12 & Australia & 27.5 & 33 & 1.6 & 2.0 & 1.8 \\
\hline 14 & 14 & Canada & 20.6 & 13 & 1.2 & 1.3 & 1.2 \\
\hline 15 & 15 & Turkey & 18.2 & 46 & 1.0 & 2.2 & 2.2 \\
\hline \multicolumn{3}{|c|}{ Total top 15} & 1396 & . & 80 & . & . \\
\hline \multicolumn{3}{|c|}{ World total } & 1739 & 9.8 & 100 & 2.2 & 2.4 \\
\hline
\end{tabular}

[] = SIPRI estimate; GDP = gross domestic product.

${ }^{a}$ Rankings for 2016 are based on updated military expenditure figures for 2017 in the current edition of the SIPRI Military Expenditure Database. They may therefore differ from the rankings for 2016 given in SIPRI Yearbook 2017 and in other SIPRI publications in 2017.

${ }^{b}$ The figures for military expenditure as a share of GDP are based on estimates of 2017 GDP from the International Monetary Fund World Economic Outlook and International Financial Statistics databases.

\section{THE TOP 15 MILITARY SPENDERS IN 2017}

The 15 countries with the highest military spending in 2017 were the same as those in 2016, but with a few notable changes in their ranking (see table 1). ${ }^{3}$ These 15 countries accounted for $\$ 1396$ billion, or 80 per cent, of total global spending.

Six of the 15 made large increases (of more than 30 per cent) in their military spending between 2008 and 2017: China, Turkey, India, Russia, Saudi Arabia and Australia. Three made more moderate increases (of 10-30 per cent)-South Korea, Brazil and Canada-and three made minor increases (of less than 10 per cent)-Germany, France and Japan. Military spending fell over the decade in three of the 15-Italy, the United Kingdom and, most notably, the United States, where spending fell by 14 per cent, equivalent to $\$ 95$ billion (in constant 2016 prices).

Among the 15 largest spenders, Saudi Arabia had the highest military burden in 2017, at 10 per cent of GDP, while Japan had the lowest, at 0.9 per cent of GDP.

There is a spending gap between the top five spenders-the USA, China, Saudi Arabia, Russia and India-and the rest of the top 15 countries. While these five all allocated over $\$ 60$ billion to their militaries in 2017, all but one of the other 10 countries spent less than $\$ 50$ billion

(the exception being France which spent $\$ 57.8$ billion). Together, the top five accounted for 60 per cent of global military spending in 2017.

At $\$ 610$ billion, US military spending accounted for more than a third of the world total in 2017. The USA's spending was 2.7 times greater than the next highest spender, China; indeed, the USA spent more than the next seven highest spenders combined (see figure 2). While US military expenditure had fallen each year since 2010, in 2017 it was unchanged from 2016. However, the US military budget for 2018 has been set at a substantially higher level ( $\$ 700$ billion). The higher spending is to support increases in military personnel and the modernization of conventional and nuclear weapons.

China allocated an estimated $\$ 228$ billion to its military in 2017, an increase of 5.6 per cent compared with 2016. This increase was the lowest

\footnotetext{
${ }^{3}$ The United Arab Emirates should be among the 15 largest spenders, probably ranking in the range 11-15, but a lack of data since 2014 means that no reasonable estimate of its military spending can be made, and it has thus been omitted from the ranking of the top 15 .
} 
since 2010 but remains in line with GDP growth plus inflation, and China's military burden thus stayed at 1.9 per cent of GDP.

Saudi Arabia was the third largest spender in 2017 following a 9.2 per cent increase in military expenditure to $\$ 69.4$ billion. By contrast, Russia's military spending fell by 20 per cent to $\$ 66.3$ billion, making it the fourth largest spender. India, where spending rose by 5.5 per cent in 2017 to $\$ 63.9$ billion, moved from sixth place to fifth in the rankings in 2017, overtaking France.

Seven of the 15 highest spenders are members of the North Atlantic Treaty Organization (NATO): the USA (rank 1), France (rank 6), the UK (rank 7), Germany (rank 9), Italy (rank 12), Canada (rank 14) and Turkey (rank 15). Together, these seven accounted for 48 per cent ( $\$ 827$ billion) of global military expenditure. Total spending by all 29 NATO members was $\$ 900$ billion in 2017.

\section{REGIONAL TRENDS}

Total regional military spending fell in Africa (by 0.5 per cent) and in Europe (by 2.2 per cent) between 2016 and 2017. The decrease in Africa was its third consecutive annual fall in military spending, while that in Europe was the first since 2013. Military expenditure in the Americas remained unchanged in 2017, but was 11 per cent lower than in 2008. By contrast, military spending in Asia and Oceania rose for the 29th successive year, this time by 3.6 per cent. Military expenditure for countries in the Middle East for which data is available also grew in 2017, by 6.2 per cent, and was 29 per cent higher than in 2008 for these countries.

The military burden varies widely between regions and between countries. Together, states in the Americas had the lowest military burden in 2017, averaging 1.3 per cent of GDP; this rises to 1.6 per cent in Europe, 1.7 per cent in Asia and Oceania, 1.8 per cent in Africa and 5.2 per cent in the Middle East.

\section{Africa}

Military expenditure in Africa was marginally down in 2017 , by 0.5 per cent to an estimated $\$ 42.6$ billion or 2.5 per cent of global military spending (see table 2). This continued the downward trend from the post-cold war peak reached in 2014, although the decrease tapered off in 2017. Despite three consecutive years of decreases, military expenditure in Africa was still 28 per cent higher in 2017 than in 2008.

Military spending in North Africa fell by 1.9 per cent between 2016 and 2017 to an estimated $\$ 21.1$ billion (see figure 3). This was the first annual decrease in military spending in the subregion since 2006. Nonetheless, spending in 2017 was 105 per cent higher than in 2008. Algeria, Africa's largest spender, decreased its military expenditure by

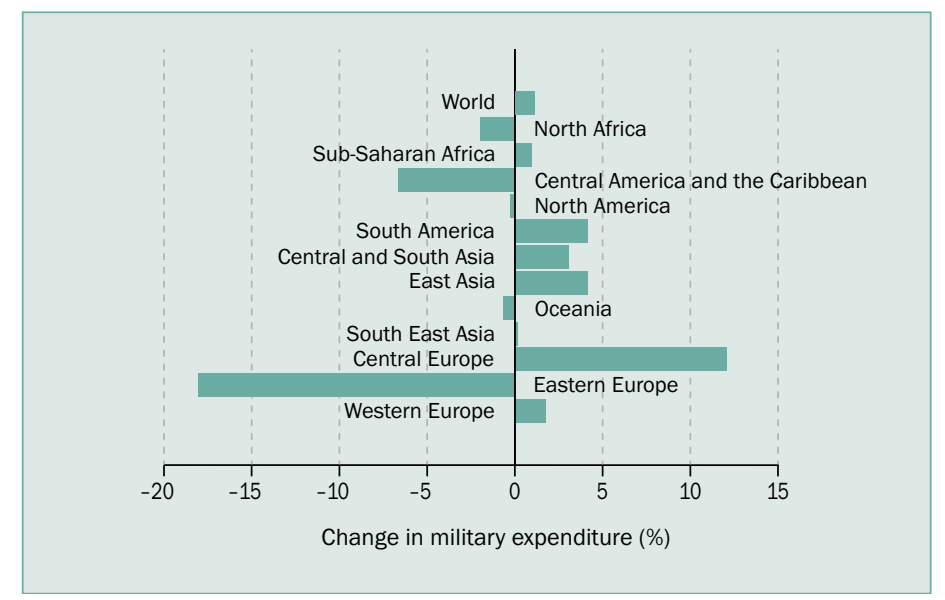

Figure 3. Changes in military expenditure by subregion, 2016-17

Note: No estimate of change in military expenditure in the Middle East is given since data for 2015-17 is highly uncertain. However, an estimate for the Middle East is included in the estimated world total. 
5.2 per cent between 2016 and 2017 to $\$ 10.1$ billion. This was the first annual decrease in its military spending since 2003 and only the second annual

Table 2. Military expenditure in Africa

\begin{tabular}{llll}
\hline & \multirow{2}{*}{ Spending, } & \multicolumn{2}{c}{ Change (\%) } \\
\cline { 3 - 4 } & $2017(\$$ b.) & $2016-17$ & $2008-17$ \\
\hline Africa $^{b}$ & $(42.6)$ & -0.5 & 28 \\
North Africa & $(21.1)$ & -1.9 & 105 \\
Sub-Saharan $_{\text {Africa }}{ }^{b}$ & 21.6 & 0.9 & -6.8 \\
Afry & & & \\
\hline
\end{tabular}

()$=$ uncertain estimate.

${ }^{a}$ Changes are in real terms.

${ }^{b}$ Total excludes Eritrea and Somalia for which it was not possible to make a reliable series of estimates. decrease since 1995. The decline in Algeria's military expenditure in 2017 was probably related to low oil and gas revenues in recent years.

Military expenditure in sub-Saharan Africa in 2017 was $\$ 21.6$ billion, up 0.9 per cent from 2016 but 6.8 per cent lower than in 2008. A substantial surge in Sudan's military expenditure in 2017 (by 35 per cent to $\$ 4.4$ billion)-mainly due to intensified fighting between the Sudanese Government and rebels-drove the upward trend, but this was partly counteracted by decreases by three of the four largest spenders in the subregion: Angola, Nigeria and South Africa. Principal of those was the continued drop in Angola's military expenditure (by 16 per cent) as part of government spending cuts. While Angola was the largest military spender in sub-Saharan Africa in 2014 with 26 per cent of the subregional total, it fell to third in 2017 (with 14 per cent of the total), behind Sudan and South Africa.

Nigeria's military expenditure fell for the fourth consecutive year in 2017, by 4.2 per cent to $\$ 1.6$ billion, despite continued military operations against Boko Haram. Military spending in South Africa, the second largest spender in sub-Saharan Africa, has stabilized at around $\$ 3.6$ billion per annum since 2012. Its military spending decreased marginally in 2017, by 1.9 per cent.

There were also notable cuts in military spending in 2017 in South Sudan ( -56 per cent), Chad ( -33 per cent), Mozambique ( -21 per cent) and Côte d'Ivoire (-19 per cent; see table 6 on page 7$)$. The decline in Côte d'Ivoire's military spending, the first annual decrease since 2013, was the result of the sharp drop in world prices for cocoa, the country's main export. In South Sudan, despite the ongoing conflict, the worsening economic conditions led to further reductions in military spending.

Table 3. Military expenditure in the Americas

\begin{tabular}{|c|c|c|c|}
\hline & \multirow{2}{*}{$\begin{array}{l}\text { Spending, } \\
2017 \text { (\$ b.) }\end{array}$} & \multicolumn{2}{|c|}{ Change (\%) ${ }^{a}$} \\
\hline & & $2016-17$ & $2008-17$ \\
\hline Americas $^{b}$ & 695 & 0.0 & -11 \\
\hline $\begin{array}{l}\text { Central America } \\
\text { and Caribbean }\end{array}$ & 7.6 & -6.6 & 39 \\
\hline North America & 630 & -0.2 & -13 \\
\hline South America & 57.0 & 4.1 & 17 \\
\hline
\end{tabular}

${ }^{a}$ Changes are in real terms.

${ }^{b}$ Total excludes Cuba.

\section{The Americas}

At $\$ 695$ billion, military expenditure in the Americas in 2017 accounted for 40 per cent of global military spending. Military expenditure in the region was unchanged from 2016 but was 11 per cent lower than in 2008 (see table 3). Spending by the two countries in North America (Canada and the USA) accounted for 91 per cent of the total for the Americas. North America's total of $\$ 630$ billion was almost unchanged from 2016 ( -0.2 per cent) and 13 per cent lower compared with 2008. South American military spending grew by 4.1 per cent to $\$ 57.0$ billion, the first annual rise since 2014, bringing the increase since 2008 to 17 per cent. Between 2016 and 2017 spending in Central America and the Caribbean fell by 6.6 per cent to $\$ 7.6$ billion, but this was still 39 per cent higher than in 2008.

The rise in military expenditure in South America between 2016 and 2017 can mainly be attributed to the increases by Argentina (by 15 per cent to $\$ 5.7$ billion) and Brazil (by 6.3 per cent to $\$ 29.3$ billion). The increase in Brazil's military expenditure, the first annual increase since 2014 and 
the largest since 2010, comes as a surprise given the country's current economic and political turmoil. However, in 2017 the Brazilian Government loosened its budget deficit targets up to 2020 and released additional funds ( $\$ 4.1$ billion) for all major sectors, including the military.

Venezuela, amid a year of social and political unrest, increased its military spending in 2017 by 19 per cent compared with 2016, the first annual rise since 2013. However, the ongoing economic crisis in the country meant that military spending in 2017 was still 75 per cent lower than in 2008.

Changes in military expenditure in Central America and the Caribbean are influenced mainly by spending by Mexico, which accounts for 76 per cent of the subregion's spending. While the military has been combating Mexico's drug cartels for many years, economic pressures (e.g. a high budget deficit and government debt) continue to limit government expenditure. At $\$ 5.8$ billion, Mexico's military spending in 2017 was 8.1 per cent lower than in 2016, down for the second consecutive year.

\section{Asia and Oceania}

Military spending in Asia and Oceania reached $\$ 477$ billion in 2017, 3.6 per cent higher than in 2016 and 59 per cent higher than in 2008 (see table 4). It was the second largest region in terms of military spending in 2017, accounting for 27 per cent of global military expenditure. The annual increase in 2017 was the lowest since the 2.4 per cent rise in 2010. Spending in 2017 increased in Central and South Asia (3.0 per cent) and East Asia (4.1 per cent), remained constant in South East Asia (up by 0.1 per cent) and was marginally down in Oceania (by 0.6 per cent). Between 2008 and 2017 military expenditure rose in all subregions, ranging from 32 per cent in Oceania to 68 per cent in East Asia.

The largest relative increases in military spending between 2008 and 2017 were made by Cambodia (332 per cent), Bangladesh (123 per cent), Indonesia (122 per cent) and China (110 per cent). There were other significant increases (higher than 40 per cent, but less than 100 per cent) in Viet Nam, the Philippines, Kyrgyzstan, Myanmar, Pakistan, Nepal and India. Only five countries in Asia and Oceania decreased spending over the decade: Timor-Leste, Afghanistan, Fiji, Malaysia and Brunei Darussalam.

Military expenditure in Asia and Oceania rose from 17 per cent of global military spending in 2008 to 27 per cent in 2017 . This was due primarily to China's spending rising from 5.8 per cent to 13 per cent of world military expenditure over the period. Five of the top 15 global spenders in 2017 are in this region: China (rank 2), India (rank 5), Japan (rank 8), South Korea (rank 10) and Australia (rank 13). The long-standing tensions between many Asian countries remain the principal driving force behind the rising trend of military expenditure in the region.

China's military spending, at an estimated $\$ 228$ billion, accounted for 48 per cent of the regional total and was 3.6 times that of the region's second largest spender, India. India spent $\$ 63.9$ billion on its military in 2017 , an increase of 5.5 per cent compared with 2016 and of 45 per cent since 2008 . 
The Indian Government plans to expand, modernize and enhance the operational capability of its armed forces motivated, at least partially, by tensions with China and Pakistan.

Military spending by Japan was $\$ 45.4$ billion in 2017, unchanged from 2016 and 4.4 per cent higher than in 2008. Perceived threats from China and North Korea remain the most important factors in Japan's security strategy. South Korea's spending increased by 1.7 per cent between 2016 and 2017 to $\$ 39.2$ billion, the lowest annual rise since 2011.

\section{Europe}

At $\$ 342$ billion, military spending in Europe accounted for 20 per cent of global military expenditure in 2017. Military spending in Europe was 2.2 per cent lower than in 2016 and was only marginally higher (1.4 per cent) than in 2008 (see table 5). Between 2016 and 2017 military spending increased in Central Europe by 12 per cent to $\$ 24.1$ billion and in Western Europe by 1.7 per cent to $\$ 245$ billion, while it fell substantially in Eastern Europe, by 18 per cent to $\$ 72.9$ billion. Over the decade $2008-17$ military spending rose in Central Europe and Eastern Europe by 20 and 33 per cent, respectively, while it fell in Western Europe by 5.7 per cent.

Four of the 15 largest military spenders in the world are in Western Europe: France (rank 6), the UK (rank 7), Germany (rank 9) and Italy (rank 12). Together, they accounted for 10 per cent of global military expenditure in 2017, down from 15 per cent in 2008. West European spending since 2008 can be depicted in a U-shaped curve: a decrease between 2009 and 2014 followed by an increase.

Between 2016 and 2017 France's spending fell by 1.9 per cent to $\$ 57.8$ billion, the first annual decrease since austerity measures ended in 2013. This followed the new French Government's pledge to trim the 2017 military budget as a way to reduce the country's budget deficit.

British military spending rose by 0.5 per cent to $\$ 47.2$ billion in 2017. This real-terms growth rate is in line with a government announcement made in May 2017 that the military budget would increase by at least 0.5 per cent above the rate of inflation, a rate matched in previous years.

Germany's military spending rose by 3.5 per cent in 2017 after a 4.2 per cent increase in 2016. At $\$ 44.3$ billion, spending in 2017 was at its highest level since 1999.

Driven by the perceived threat from Russia felt by many countries in Central Europe, military expenditure in the subregion rose by 12 per cent

Table 5. Military expenditure in Europe

\begin{tabular}{lccc} 
& \multirow{2}{*}{ Spending, } & \multicolumn{2}{c}{ Change $(\%)^{a}$} \\
\cline { 3 - 4 } & $2017(\$ \mathrm{~b})$. & $2016-17$ & $2008-17$ \\
\hline Europe & 342 & -2.2 & 1.4 \\
Central Europe & 24.1 & 12 & 20 \\
Eastern Europe & 72.9 & -18 & 33 \\
Western Europe & 245 & 1.7 & -5.7 \\
\hline
\end{tabular}

${ }^{a}$ Changes are in real terms. in 2017. Military spending has now risen for four consecutive years (2014-17) following six consecutive annual decreases between 2008 and 2013. While Poland was by far the largest military spender in Central Europe in 2017, accounting for 42 per cent of the subregional total, Romania made the largest relative increase: its military expenditure rose by 50 per cent, the highest rate of increase in the world between 2016 and 2017 (see table 6). This sharp rise was due to Romania starting to implement its military procurement, modernization and expansion plan for 2017-26. Other notable increases in 
Table 6. The biggest increases and decreases in military spending, 2016-17

Spending figures are in US\$, at current prices and exchange rates. Changes are in real terms, based on constant (2016) US dollars.

\begin{tabular}{|c|c|c|c|c|c|c|}
\hline Rank & Country $^{a}$ & $\begin{array}{l}\text { Military spending, } \\
2017 \text { (\$ m.) }\end{array}$ & $\begin{array}{l}\text { Increase (\%), } \\
2016-17\end{array}$ & Country ${ }^{a}$ & $\begin{array}{l}\text { Military spending, } \\
2017 \text { (\$ m.) }\end{array}$ & $\begin{array}{l}\text { Decrease (\%), } \\
2016-17\end{array}$ \\
\hline 1 & Romania & 4004 & 50 & South Sudan & 72 & -56 \\
\hline 2 & Gabon & 299 & 42 & Chad & 210 & -33 \\
\hline 3 & Benin & 116 & 41 & Myanmar & 1709 & -28 \\
\hline 4 & Sudan & 4383 & 35 & Peru & 2086 & -23 \\
\hline 5 & Mali & 461 & 26 & Mozambique & 103 & -21 \\
\hline 6 & Burkina Faso & 191 & 24 & Oman & 8687 & -20 \\
\hline 7 & Iraq & 7416 & 22 & Russia & 66335 & -20 \\
\hline 8 & Cyprus & 395 & 22 & Côte d'Ivoire & 496 & -19 \\
\hline 9 & Lithuania & 812 & 21 & Angola & 3063 & -16 \\
\hline 10 & Philippines & 4378 & 21 & Malaysia & 3495 & -16 \\
\hline 11 & Latvia & 514 & 21 & Burundi & 64 & -15 \\
\hline 12 & Cambodia & 463 & 21 & Uganda & 445 & -15 \\
\hline 13 & Venezuela & 465 & 19 & Congo, Republic of the & 484 & -14 \\
\hline 14 & Niger & 200 & 19 & Brunei Darussalam & 347 & -14 \\
\hline 15 & Luxembourg & 318 & 19 & Namibia & 434 & -11 \\
\hline
\end{tabular}

${ }^{a}$ The list shows the countries with the largest increases or decreases in the world. Countries with military expenditure in 2017 of less than $\$ 100 \mathrm{~m}$. (or $\$ 50 \mathrm{~m}$. in Africa) are excluded.

spending in the subregion were those of Latvia and Lithuania, both of which increased their military spending by 21 per cent.

The fall in military spending in Eastern Europe in 2017 was the first annual decrease since 2008. The decline was due almost entirely to the fall in Russian military expenditure, which in 2017 accounted for 91 per cent of the subregional total. The Russian economy has suffered a number of setbacks since 2014, including a significant drop in oil export revenues, and government spending has been falling since then. However, military spending kept increasing until 2017, when it fell for the first time since 1998. In 2017 Russian military spending was $\$ 66.3$ billion, a real-terms decrease of 20 per cent compared with 2016. The fall in spending in 2017 brought the military burden down to 4.3 per cent of GDP, from 5.5 per cent in 2016. However, this share of GDP was still higher than any other European country had recorded since 2011.

Ukraine's military expenditure in 2017 was $\$ 3.6$ billion. While spending increased by 10 per cent in nominal terms, high inflation meant that it fell in real terms by 2.0 per cent. This is similar to the change in 2016 and very different from the strong real-terms growth in 2014-15. Improved economic conditions in Ukraine since 2016 have reduced its military burden from a high of 4.0 per cent of GDP in 2015 to 3.4 per cent in 2017.

\section{The Middle East}

SIPRI has not estimated total military spending in the Middle East in 2017 because of a lack of accurate data for Qatar, Syria, the United Arab Emirates (UAE) and Yemen. The combined military expenditure of those countries in the region for which data is available in 2017 increased continuously between 2009 and 2015, resulting in a total increase of 41 per cent. However, with the fall in oil prices, military spending by these countries decreased by 
SIPRI is an independent international institute dedicated to research into conflict, armaments, arms control and disarmament. Established in 1966, SIPRI provides data, analysis and recommendations, based on open sources, to policymakers, researchers, media and the interested public.

\section{GOVERNING BOARD}

Ambassador Jan Eliasson, Chair (Sweden)

Dr Dewi Fortuna Anwar (Indonesia)

Dr Vladimir Baranovsky (Russia)

Ambassador Lakhdar Brahimi (Algeria)

Espen Barth Eide (Norway)

Ambassador Wolfgang Ischinger (Germany)

Dr Radha Kumar (India)

Dr Jessica Tuchman Mathews (United States)

\section{DIRECTOR}

Dan Smith (United Kingdom)

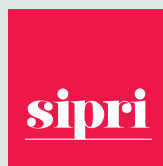

STOCKHOLM INTERNATIONAL PEACE RESEARCH INSTITUTE Signalistgatan 9 SE-169 72 Solna, Sweden Telephone: +4686559700 Email:sipri@sipri.org Internet: www.sipri.org
16 per cent between 2015 and 2016. Their spending increased again in 2017, by 6.2 per cent, but their total was still 11 per cent lower than in 2015 .

Saudi Arabia is by far the largest military spender in the region and was the third largest in the world in 2017. Its military spending increased by 74 per cent between 2008 and 2015 to a peak of $\$ 90.3$ billion. It then fell by 29 per cent in 2016, but increased again by 9.2 per cent in 2017 to $\$ 69.4$ billion.

Between 2008 and 2017 Turkey's military expenditure increased by 46 per cent to reach $\$ 18.2$ billion, making it the 15 th largest spender globally. It would probably rank 16th if data were available for the UAE. The last available estimate for the UAE's military spending is for 2014, when at $\$ 24.4$ billion it was the second largest military spender in the region. Considering its ongoing military operations abroad and large arms procurement projects, it is reasonable to assume that its military spending remains at a similar level to 2014.

By 2014 Iran's military expenditure had declined steadily (by 31 per cent) from its peak in 2006. However, since 2014 the Iranian economy has benefited from the gradual lifting of European Union and United Nations sanctions, which in turn facilitated a 37 per cent increase in military spending between 2014 and 2017 to $\$ 14.5$ billion in 2017.

Following a peak in Israel's spending in 2014-15, which coincided with its military operations in Gaza in 2014, Israel's military expenditure dropped by 13 per cent between 2015 and 2016 . While military spending increased by 4.9 per cent to $\$ 16.5$ billion in 2017 (excluding about $\$ 3.1$ billion in military aid from the USA), this total is well below the levels of spending in 2014 and 2015.

Seven of the 10 countries with the highest military burden in the world in 2017 are in the Middle East: Oman (12 per cent of GDP), Saudi Arabia (10 per cent of GDP), Kuwait (5.8 per cent of GDP), Jordan (4.8 per cent of GDP), Israel (4.7 per cent of GDP), Lebanon (4.5 per cent of GDP) and Bahrain (4.1 per cent of GDP).

\section{The SIPRI Military Expenditure Database}

The SIPRI Military Expenditure Database provides military expenditure data by country for the years 1949-2017 in local current prices, constant US dollars, current US dollars, as a share of GDP, per capita and as a share of general government expenditure. The database and further details on the definitions, sources and methods used are available at the SIPRI website.

\section{ABOUT THE AUTHORS}

Aude Fleurant (Canada/France) is Director of the SIPRI Arms and Military Expenditure Programme. Pieter D. Wezeman (Netherlands/Sweden) and Siemon T. Wezeman (Netherlands) are Senior Researchers, Nan Tian (China/South Africa) is a Researcher and Alexandra Kuimova (Russia) is a Research Assistant in the Programme. 